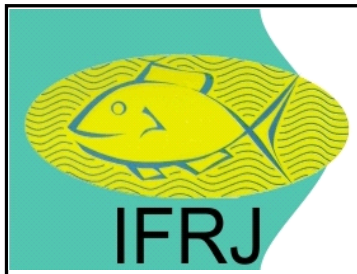

Available online at: http://ejournal-balitbang.kkp.go.id/index.php/ifrj

e-mail:ifrj.puslitbangkan@gmail.com

INDONESIANFISHERIES RESEARCHJOURNAL

Volume 27 Nomor 2 December 2021

p-ISSN: 0853-8980

e-ISSN: 2502-6569

Accreditation Number RISTEK-BRIN: 85/M/KPT/2020

\title{
CHARACTERIZING SKIPJACK TUNA (Katsuwonus pelamis) SUPPLY CHAIN OF POLE AND LINE FISHERY IN INDONESIA FMA 714 AND ADJACENTS: A CASE STUDY IN SIKKA REGENCY, WEST NUSA TENGGARA-INDONESIA
}

\author{
Agustinus Anung Widodo*1, Lilis Sadiyah ${ }^{1}$ and Fayakun Satria ${ }^{2}$ \\ ${ }^{1}$ Center for Fisheries Research, ${ }^{2}$ Research Institute for Marine Fisheries Indonesia, \\ JI. Pasir Putih II, Ancol Timur, Jakarta Utara-14430, Indonesia \\ Received; June 15-2020 Received in revised from May 27-2021; Accepted June 15-2021
}

\begin{abstract}
In order to obtain detailed characteristics of skipjack tuna (SKJ) supply chain on pole and line (PL) fishery operates in Indonesia Fisheries Management Area (I-FMA) 714 and its adjacent areas, the Center for Fisheries Research (CFR)-MMAF with WCPFC carried out a research in Sikka Regency. Data and information were obtained through port sampling program, observer program, and stakeholders workshop. Result shows that primary actors and processes of the supply chain of skipjack tuna on PL fishery based in Sikka consisted of PL fishers (skipper and crews), collector and traders, processors, and market. Total active PL boats were 67, which were supported by \pm 40 lift-net (bagan) to provide 300-400 tonnes live bait, 11 small-medium scale and 5 large scale collectors and traders, 5 small and 4 large processors, and local, domestic, and export market. About 3,556.9 tonnes SKJ caught by PL based in Sikka in 2017, about 56\% were processed as katsuobushi (smoke fish) for being exported to Japan, $35 \%$ were frozen processed for being exported and marketed to Europe-US as well as domestic market in Makassar, Bali, and Surabaya. Only about $9 \%$ of the total catch of PL fishery based in Sikka were locally marketed as cold-fresh SKJ.
\end{abstract}

Keywords: Skipjack tuna; supply chain; pole and line fishery; Sikka

\section{INTRODUCTION}

As an archipelagic country, the illegal, unreported, and unregulated (IUU) fishing is very potential (Muhamad, 2012) and remains to occur in Indonesia (Inayati, 2019). Being convinced that one of the tools for combating IUU fishing is catch documentation schemes (CDS). The CDS is a "traceability framework" or system, and the supply chain is a fundamental attribute determining the success of a CDS (Hosch, 2016). Supply chain describes the full range of product flow and activities needed from production to the final product at the end consumers, through the various stages of production, including production inputs, physical transformation of the product, and product distribution to final consumers (Beamon, 1998, Kaplinsky \& Morris 2001; Gereffi et al., 2005; Bjorndal, et al. 2014). Gibbon et al. (2008) and Bair (2009) added the supply chain needs to integrate to attributes of actors involved in each node (called: sector) from production to marketing. Conducting business requires an integrated network of firms competing with each other in "supply chain" (Christopher, 2011). In the tuna including skipjack fisheries case, the supply chain covers information related to activities and inputs needed at harvesting node as well as fishers attributes, processing activities and characteristics of processing companies, and types of wholesalers and traders as well as the nature in which catches are distributed between domestic and export markets.

Skipjack tuna was commercially exploited in Indonesian waters including I-FMA 713-717, which are parts of the Western and Central Pacific Fisheries Commission (WCPFC) statistical areas. In Indonesia, skipjack tuna is caught mostly with tuna purse seiners (PS), pole and lines (PL), trolling lines, and surface handline and long line (HL-TR) and to a small extent by drifting gillnets (d-GN) and tuna long line (LL). Except $d-G N$ and $L L$, the fishing gears mostly use Fish Aggregating Devices (FADs) in their fishing (Widodo et al. 2020). Research on the supply chain in Indonesia has been widely carried out including Sari (2015), Athaillah et al. (2018), and Barclay et al. (2020). Unfortunately, the researchers did not provide detailed information on each node attribute of the 
supply chain. Meanwhile, it is very important, as it will provide better understanding of conditions affecting the occurrence of risk events, their causes, and relevant mitigation strategies (Sutrisno, et al., 2019). Naziratil et al. (2020) mentioned that the importance of knowing skipjack tuna supply chain systems is to reduce the risk of uncertainty, in the form of both production and distribution. In order to obtain detailed view of supply chain of skipjack tuna caught by $\mathrm{PL}$ in I-FMA 714 and adjacents, the Center for Fisheries Research-MMAF Republic of Indonesia had a collaborative research with WCPFC that was funded by WCPFC-WPEA Project year of 2017 and carried out in Sikka Regency.

\section{MATERIALSAND METHODS}

The selected fishing gear used in the study is PL or 'huhate' based in Sikka Regency with the main fishing grounds are in Banda Sea (I-FMA 714) and its adjacent waters (Figure 1). The main target of PL is skipjack tuna (SKJ) with bycatch includes juvenile of yellowfin tuna (j-YFT), juvenile of bigeye tuna (j-BET), neritic tuna particularly kawa-kawa (KAW), and several big pelagic fish species as well.
The data and information were obtained through port sampling program, observer program, and focus group discussion (FGD). Port sampling program was conducted by four enumerators, who collected data of catch $(\mathrm{kg})$ and biology aspects (species and size of species) of every PL landing in the private fishing port of Karya Cipta Buana Sentosa (KCBS) Co. Ltd and in Wuring Fishing Port every day in JanuaryDecember 2017.

Observer program was carried out by two observers who were deployed in PL boats at sea. Observer program conducted for three months (October December 2017). The data collected on the observer program covers fishing operational data, catch, and biology aspects, i.e. species and size. Focus Group Discussion (FGD) was conducted in Maumere-Sikka Regency in the middle of November 2017. The participants of the stakeholders workshop or FGD were PL fishers (skippers and crews), PL owners, tuna traders, tuna companies, Sikka DKP officers, researchers, and DGCF officers. The data collected in FGD covers social-economic data and information including fish price and type of tuna companies.

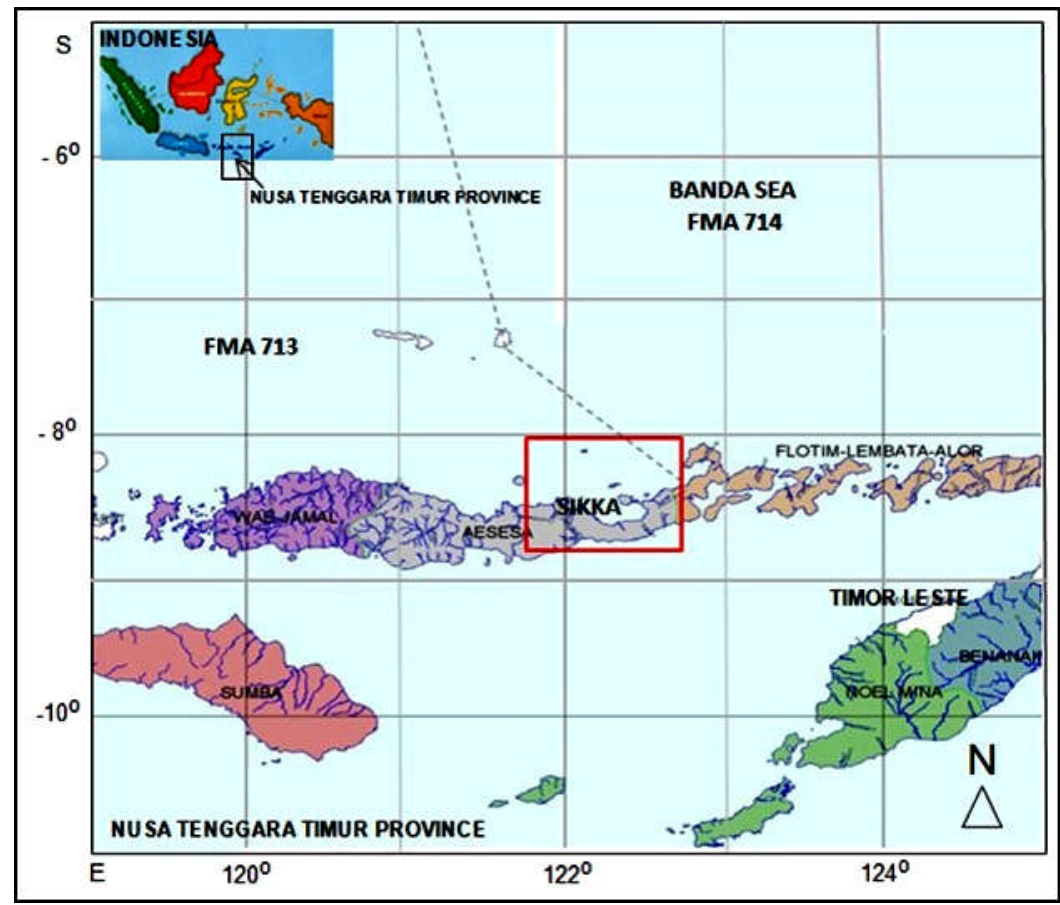

Figure 1. Location of Study Site (red box).

\section{Data Analyses}

Descriptive analyses are often used in social science and business research (Baha, 2016), in which the research on supply chain can be cate gorized. Therefore, descriptive analysis was considered to be used in this study to describe the characteristic nodes (sectors), including harvesting, processing and distribution. The nominal Catch Per Unit Effort (CPUE) of $P L$ in the harvesting node was calculated using equation by Petrere et al. (2010) below: 


$$
\text { CPUE } \frac{\sum c i}{\sum f i}=\frac{\bar{c}}{\bar{f}}
$$

where, $c_{i}$ is catch (tonnes), and $f_{i}$ is respective fishing effort (effective day of fishing). The results of analyses are presented in tables, graphs and in interpreted narration.

\section{RESULTS AND DISCUSSION Results}

The skipjack tuna (SKJ) supply chain in Sikka consists of several nodes (sectors) including the harvesting sector, processing sector and distributing sector.

\section{Harvesting Node}

The harvesting node consists of fishing gear and fleet, fishing operation (fishing ground, live bait use, and catch) and socio-economics of fishers.

\section{Fishing Gear and Boat}

Mainly, the fishing gears for catching skipjack in Sikka were pole and line (PL), local name 'huhate', combination of surface hand line and trolling line ( $\mathrm{HL}-$ TR). HL-TR were usually operated by fishing boats under a local name called 'kapal penongkol'. The fishing operated alternately depending on season, prevailing seas, sea conditions, and catch success. PL fisheries contribute almost $80 \%$ of total SKJ that were landed in Sikka in 2017, and about $20 \%$ was caught by a variety of fishing gear including s-GN and the HL-TR. PL fishery based in Sikka started from one unit boat in 1980, then 9 unit boats in 1983, afterward 19 boats in 1985 and became 48 boats in 1988. All boats used during that period were made by wooden boat construction. Partnership collaboration project between Directorate General of Capture Fisheries and a fishing company called PT. Bali Raya constructed 26 fiberglass fishing boats (Fig. 2), and in 1988 became 74 units. Mr. Heribertus Krispinus, the Head of Marine Affairs and Fisheries Office or Kantor DKP of Sikka Regency in 2017, added that the size of wooden boats were 20-35 GT, whereas fiberglass boats ranged 15-20 GT.

The number of the PL boats that registered in DKPSikka in 2017 were 75 units but only 67 units were actively operated, mostly 30-35 GT (Fig. 3).

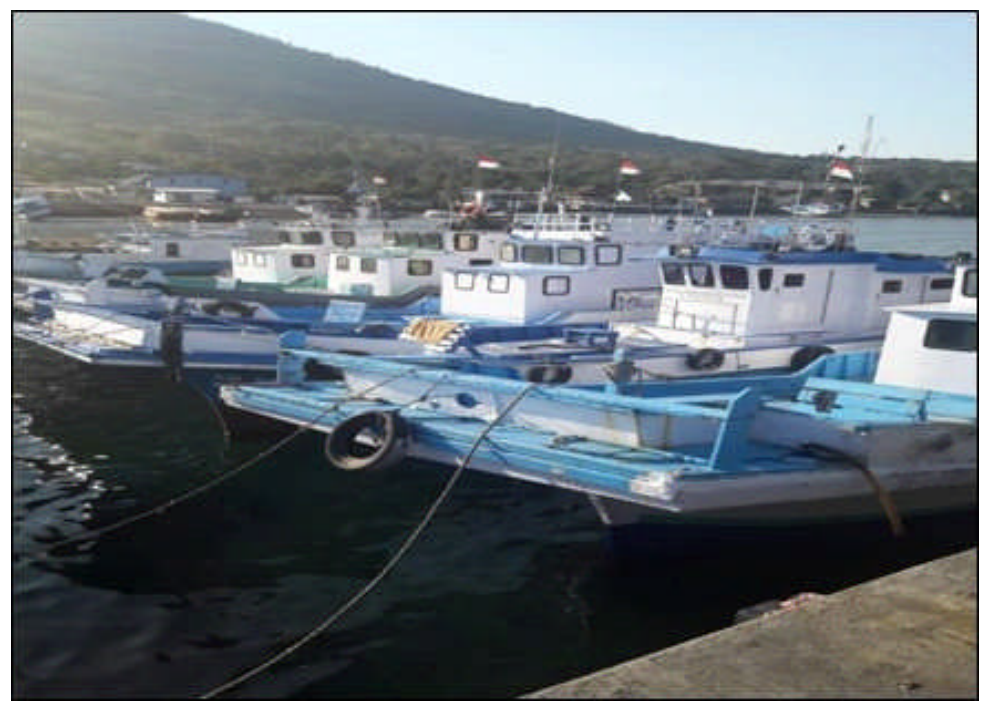

Figure 2. Type of PL boats 20 GT (fiberglass) based in Sikka and adjacent areas. 


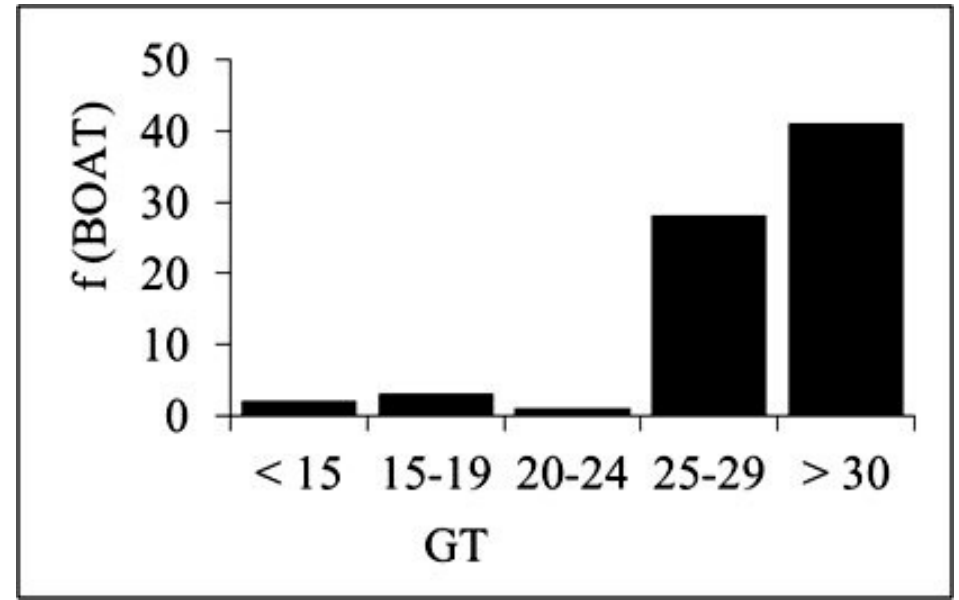

Figure 3. Registered PL boats in Sikka Regency (DKP Sikka, 2017).

\section{Fishing Operation}

The PL fishing method involved two interlinked fisheries; those were live bait and tuna fisheries. Live bait was provided by lift-net (called bagan) fisheries. Presently, the total bagan registered in DKP Sikka are about 145 units, whereas in 2017 it was only about 40-50 active bagan (DKPSikka, 2017). The sources of live bait were supplied from inshore of several islands in Sikka Regency; however, the main live bait fishing grounds were in the waters around Ndete and Pemana Islands. Each PL boat needs about 2-3 buckets (approx. 60-70 kg per bucket) live bait every day. Total production of bagan that provides live bait is estimated at approximately 300-400 tonnes per year. The observer noted that primary species of live bait fish include anchovies (Engraulis spp.), juvenile stage of scads and sardine. About $70 \%$ of total production of lift-net (bagan) or about 210-280 tonnes were used for live bait of PL boats, and the rest was for human consumption. During focus group discussion (FGD) in Sikka (Mid November 2017), it was noted that the PL fishermen had experienced scarcity of live bait catch in recent years. In one year, there were several months that PL fisheries were not operated due to the lack of live bait availability for fishing operation. The fishermen mentioned that the live bait scarcity was generally because of (1) overfishing or depletion of live baitfish resources, and (2) competition with human preferences for food.

There were 2 (two) approaches of PL fishing operation in Sikka, i.e. free shoaling and the use of FADs fishing. The fishing grounds of PL based in Sikka were mostly in I-FMA 714 and its adjacent waters including I-FMA 713. Figure 4 shows the fishing ground location of PL boats based in Sikka during the observer program in 2017.

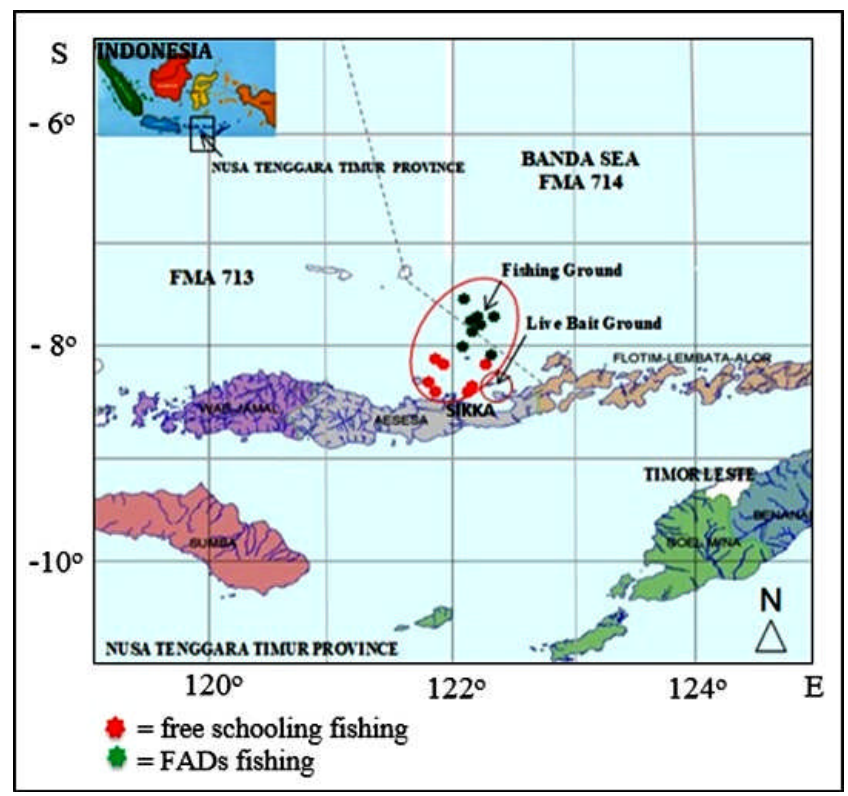

Figure 4. Fishing ground of PL boats based in Sikka. 
Catch results of skipjack in Sikka during 20132017 was 2,898.1 - 4.148,9 tonnes (Table 1) with an average of $3.801,0$ tonnes (DKP Sikka, 2017). Within the year of 2017, there were approximately3,556.9 tonnes of 3.952 .1 tonnes ( $85 \%$ ) had been caught by PL boats and the remains by s-HL-TR, i.e. about 395.2 tonnes (15\%).

Table 1. Skipjack (SKJ) production in Sikka (2013-2017)

\begin{tabular}{cccc}
\hline Year & $\begin{array}{c}\text { Total of SKJ } \\
\text { Catch (tonnes) }\end{array}$ & $\begin{array}{c}\text { Catch of SKJ From PL } \\
\text { Fisheries (tonnes) }\end{array}$ & $\begin{array}{c}\text { Catch of SKJ from other } \\
\text { Fisheries (tonnes) }\end{array}$ \\
\hline 2013 & 2898.1 & 2492.4 & 405.7 \\
2014 & 3938.2 & 3505.1 & 433.1 \\
2015 & 4067.6 & 3489.1 & 569.5 \\
2016 & 4148.9 & 3651.0 & 497.9 \\
2017 & 3952.1 & 3556.9 & 395.2 \\
Average & 3801.0 & 3340.7 & 460.3 \\
\hline
\end{tabular}

Source: DKP Sikka (2017)

A total of 309 fishing trips of PL were sampled during the port sampling program from March to November 2017 in Sikka. The sampling sites were PT. KCBS and Wuring Fish Landing. The results showed that the catch rate of $\mathrm{PL}$ boats ranged from 628 to 1,969 (average 1,020 ) $\mathrm{kg}$ per day with the lowest catch rate was in June and highest catch rate was in March (Table 2). The target of PL boats was skipjack tuna (Katsuwonus pelamis) with by-catch of juvenile of yellowfin tuna (Thunnus albacares) or j-YFT) and juvenile of bigeye tuna (Thunnus obesus) or j-BET and few of neritic tuna as well. Neritic tunas caught by PL boats include kawa-kawa (Euthynnus affinis) or KAW, longtail tuna (Thunnus tonggo) or LOT, frigate tuna-(Auxis thazard) or FRI, and bullet tuna (Auxis rochei) or BLT. The results of a port sampling program in Sikka in 2017 showed that the catch compositions were SKJ, j-YFT, j-BET and neritic tuna in percentage of $76.6 \%, 13.4 \%, 0.4 \%$ and $9.6 \%$, respectively. Size distribution $\left({ }_{c m} F L\right)$ of SKJ ranged between $28-65 \mathrm{~cm}$. The average of live bait used was 1.75 buckets $\mathrm{kg} /$ day/ boat, so that tuna-baitfish ratio was about $9.5: 1$.

Table 2. CPUE (kg/day) of PL boats based on port sampling program in Sikka (March-November 2017).

\begin{tabular}{|c|c|c|c|c|c|c|c|c|c|}
\hline \multirow{2}{*}{ Month } & \multirow{2}{*}{ Gear } & \multirow{2}{*}{$\underline{\mathrm{NL}}$} & \multirow{2}{*}{$\underline{O D}$} & \multicolumn{5}{|c|}{ Catch $(\mathrm{kg})$} & \multirow{2}{*}{$\begin{array}{c}\text { CPUE } \\
\text { (kg/day) }\end{array}$} \\
\hline & & & & SKJ & YFT & BET & Other & Total & \\
\hline Mar-2017 & $\mathrm{PL}$ & 45 & 48 & 75,906 & 14,367 & 515 & 3,730 & 94,518 & 1,969 \\
\hline Apr-2017 & PL & 63 & 61 & 35,807 & 11,726 & 370 & 8,249 & 56,152 & 921 \\
\hline May-2017 & $\mathrm{PL}$ & 47 & 24 & 33,750 & 5,323 & 195 & 5,030 & 44,298 & 1,846 \\
\hline Jun-2017 & PL & 9 & 10 & 4,655 & 1,020 & 0 & 600 & 6,275 & 628 \\
\hline Jul-2017 & $\mathrm{PL}$ & 9 & 9 & 4,060 & 875 & 90 & 915 & 5,940 & 660 \\
\hline Aug-2017 & PL & 38 & 39 & 20,224 & 3,989 & 0 & 5,756 & 29,969 & 768 \\
\hline Sep-2017 & PL & 49 & 71 & 49,243 & 4,085 & 0 & 2,815 & 56,143 & 791 \\
\hline Oct-2017 & PL & 19 & 20 & 12,650 & 1,909 & 0 & 1,340 & 16,099 & 805 \\
\hline Nov-2017 & PL & 30 & 34 & 21,235 & 1,935 & 20 & 3,875 & 27,065 & 796 \\
\hline Total & & 309 & 316 & 257,730 & 45,229 & 1,190 & 32,310 & 336,459 & 1,020 \\
\hline
\end{tabular}

$\mathrm{NL}=$ number of landing; $\mathrm{OD}=$ operation day

\section{Socio-economics of fishers}

The results of stakeholders FGD showedthat there were two systems of PL fleet ownership, i.e. individual and companies owner. There were $67 \mathrm{PL}$ boats in Sikka, 63 boats owned by individual fishermen, while the remaining 4 boats belonged to KCBS Co. Ltd. This company also has a fishing and processing unit company. It is also obtained from the workshop that at least three business collaboration/partnership models (patterns) among PL boats owners, SKJ collectors/buyers and SKJ processing as follows:
- independent model: PL boat owners that have no collaboration with any collecting company/buyers; - plasma model: PL boat owners that have mutual relationships with collecting/processing companies including operational cost support. The company first provides the operational cost of the fishing operation; the cost is then balanced from the total revenue to recover the first cost.

- company owned PL boats: legal status of company can be either CV or Co Ltd.; may have a particular fishing company or integrated operation with a processing company. 
Independent model was the fisheries model owned by individuals or groups and independently operated, not supported by other counterparts, either from the capital aspect or any other kind of support. Plasma model is the model developed by a processing company that was integrated with some PL fishers as their plasma. The company supports in a form of logistics and provides Fish Aggregating Devices (FAD) to fishermen, and vice-versa, where the plasma fisherman might be available to sell their catch product to the processing company. The ownership model company was the model owned by processing company and PL boats where the boat's fishing catch was used as the raw materials of the processing unit. The price of SKJ in Sikka in 2017 were varied based on the size and quality or grade (Table 3 ).

Table 3. Price of SKJ in Sikka (2017)

\begin{tabular}{ll}
\hline Quality (grade) & Price (IDR) \\
\hline Grade A & 15,550 \\
Grade B & 14,350 \\
Grade C & 14,000 \\
Grade D & 13,350 \\
\hline
\end{tabular}

\section{Processing Node}

The number of fisheries companies based in Sikka were 26 (DKPSikka, 2017), which varied on business scales, i.e. fishing company, processing company, as well as fish traders/collectors (Table 4). There were three SKJ main companies: PT. KCBS, PT. Shitaratian, and PT. Okishin Flores, which had business operations as fisheries companies, collectors and processing companies. From total fish caught by PL boats (3,556.9 tonnes), about 2011.9 tonnes $( \pm 56.6 \%)$ were processed as smoke fish (katsuobushi) by PT. KCBS, $1,224.9$ tonnes $( \pm 34.4 \%$ ) as frozen fish by PT. Shitaratian and PT. Okishin Flores and the remains, about 320.1 tonnes ( \pm $9.0 \%$ ), were marketed locally as cold-fresh skipjack. Katsuobushiproducts were exported to Japan, while frozen SKJ to Europe and USA via Bali, Makassar and Surabaya. Some frozen SKJ was marketed to the domestic market, primarily Surabaya, for cannery row material as well. Figure 5 presented katsuobushi processing in PT. KCBS and a typical local market of fresh SKJ in Wuring Fishing Port.

Table 4. Skipjack and other fisheries companies in Sikka (DKP Sikka, 2017)

\begin{tabular}{|c|c|c|c|}
\hline No & $\begin{array}{l}\text { Company (Co } \\
\text { Ltd.)/Trader }\end{array}$ & Address & Scale of Business \\
\hline 1. & KCBS (Co Ltd.) & Wailiti & $\begin{array}{l}\text { Fishing, collecting, processing (katsuobushi and } \\
\text { tuna loin) }\end{array}$ \\
\hline 2. & Shitaratian (Co Ltd.) & Hewuli & $\begin{array}{l}\text { Collecting, processing (frozen skipjack and tuna } \\
\text { loin) }\end{array}$ \\
\hline 3. & Okisin Flores (Co Ltd.) & Wuring & $\begin{array}{l}\text { Fishing, collecting, processing (fresh skipjack and } \\
\text { tuna) }\end{array}$ \\
\hline 4. & Biru Laut (Co Ltd.) & Wolomarang & Collecting of octopus and processing of tuna loin \\
\hline & $\begin{array}{l}\text { Agita Best Seafood (Co } \\
\text { Ltd.) }\end{array}$ & Paga & Collecting of fresh octopus \\
\hline 6. & Camar Laut (Trader) & Wolomarang & $\begin{array}{l}\text { Processing of tuna loin, and collecting of fresh } \\
\text { reef fish }\end{array}$ \\
\hline & $\begin{array}{l}\text { Panca Putra Mandiri } \\
\text { (Trader) }\end{array}$ & Wolomarang & Processing of tuna loin \\
\hline 8. & Pulau Mas Bahari (Trader) & Kolisia & Collecting of life grouper and lobster \\
\hline 9. & Dwi Putri (Trader) & Parumaan & $\begin{array}{l}\text { Collecting of life grouper and fresh demersal-reef } \\
\text { fish }\end{array}$ \\
\hline 10. & Bintang Mulia (Trader) & Wolomarang & Processing of fish meal \\
\hline 11. & LH. Corido (Co Ltd.) & Alok Timur & $\begin{array}{l}\text { Collecting of fresh neritic tuna, octopus, pelagic } \\
\text { fish }\end{array}$ \\
\hline & Mahadhita Karya (Co Ltd.) & Alok Timur & $\begin{array}{l}\text { Collecting of fresh sheerfish, octopus, demersal } \\
\text { fish }\end{array}$ \\
\hline 13. & Abdul Wani (Trader) & Kojodoi & $\begin{array}{l}\text { Collecting of fresh demersal-reef fish, octopus, } \\
\text { small pelagic fish }\end{array}$ \\
\hline
\end{tabular}




\begin{tabular}{|c|c|c|c|}
\hline 14. & Denpa Halang (Trader) & Nanghale & $\begin{array}{l}\text { Collecting of fresh sea cucumber, octopus, } \\
\text { demersal-pelagic fish }\end{array}$ \\
\hline 15. & Herman Kondi & Waiara & Collecting-processing of frozen skipjack. \\
\hline 16. & Taufik M. Damin (Tra & Nangahale & $\begin{array}{l}\text { Collecting of demersal fish, octopus, sea } \\
\text { cucumber }\end{array}$ \\
\hline 17. & M. Saleh Said (Trader) & Wuring & $\begin{array}{l}\text { Collecting-processing of tuna loin and frozen } \\
\text { skipjack }\end{array}$ \\
\hline 18. & Hasmi (Trader) & Wuring & Collecting-processing of tuna loin \\
\hline 19. & Pampilus Pala (Trader) & Lepolima & Collecting of fresh demersal, pelagic fish \\
\hline 20. & Saudi (Trader) & Kolisia & $\begin{array}{l}\text { Collecting of fresh octopus, pelagic fish, demersal } \\
\text { fish }\end{array}$ \\
\hline 21. & Ishak (Trader) & Nangahale & Collecting of fresh octopus and demersal fish \\
\hline 22. & Suwandi Junaidi (Trader) & Wolomarang & Collecting of fresh skipjack and neritic tuna \\
\hline 23 & Thomas (Trader) & agot & gic fish \\
\hline 24 & Yosef Beator (Trader) & Ipir-Bola & of fresh pelagis fish and neritic tuna \\
\hline 25. & Hadrawi Taher (Trader) & Nanghale & Collecting of fresh octopus and demersal-reef fish \\
\hline 26. & Hartonnesneso (Trader) & Pem & $\begin{array}{l}\text { Collecting-Processing of fresh demersal fish and } \\
\text { tuna loin }\end{array}$ \\
\hline
\end{tabular}

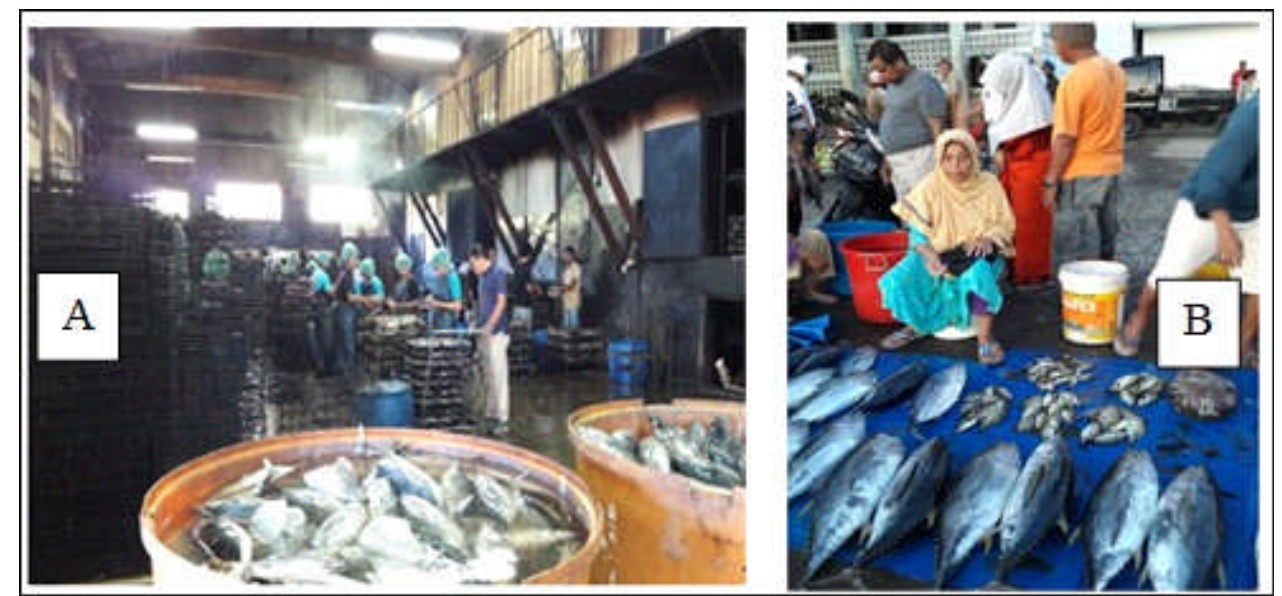

Figure 5. Katsuobushiplan at KCBS Co. Ltd (A) and fresh SKJ including j-YFT and j-BET that were sold in Wuring fishing Port (B).

\section{Persons and Processes}

All fisheries business persons and processes in SKJ product road on PL fishery from ocean to plate should be identified clearly. Supply chain mapping was a key activity to ensure that all persons and processes were identified. Through field observation and stakeholder meetings, the information of persons and processes involved in SKJ road products on supply chain PL fisheries based in Sikka has been identified (Table 4). The overview of SKJ supply chain of PL fishery based in Sikka is presented in Figure 6 .

Live baits from bagan (lift-net) were bought by PL fishers in Ndete and Pemana Islands. The total of registered lift-nets (bagan) in Sikka were about 145 units but approximately 30-40 only were active. About 300-400 tonnes of mix anchovies and juvenile scads and sardine were caught by the 30-40 active bagan (lift-net) yearly, comprising around $30 \%$ fresh anchovies for food and $70 \%$ live anchovies for bait.
Total registered PL boats in Sikka were 75 but only about 67 boats were active in 2017, consisting 5 (7\%) PL boats owned by companies, $20(30 \%)$ boats owned by individual fishers, which were under mutual agreement between partnership plasma and companies, and 42 (63\%) boats were independent. The company-owned boats and plasma boats usually landed their catch in a private port owned by KCBS Co Ltd, and the independent boats usually landed the fish in Wuring (Government) Fishing Port. The fish catch landed in a private port then was brought down to large scale processor (called: katsuobushi processing) plants and cold storages. Whereas the catchlanded in the Government Fishing Port was processed in small-medium and large processors by small-medium and large traders-collectors. Figure 6 presents a full flow chart of the SKJ road line from the ocean to the end consumer. 
Table 4. Actors and processes on the product of SKJ journey on supply chain PL fisheries based in Sikka.

\section{Actors}

PL Fishers (captain and crew)

- 67 active boats (20-40 GT) including 4 dependent boats and 63 independent boats.

- $\quad$ Supported by \pm 40 active lift-net (bagan) and \pm 60 FADs.

Processes

Fishing (FADs and nonFADs)

Trading

Processing

5 small scale processor including fresh-cold, loin and abon
4 large scale processor including frozen and smoke (katsuobushi) Market

- Local including Sikka and adjacents including traditional markets Distributing and restaurants

Domestic including Bali, Makassar, and Surabaya.

Export including Japan, Europe, and the USA.



Figure 6. Road overview of SKJ on PL fisheries based in Sikka, East Nusa Tenggara, Indonesia 


\section{Discussion}

In general, the tuna, including SKJ, supply chain in eastern Indonesia involves numerous persons or performers that play different roles. For example, tuna supply in Bitung involves small and large-scale fishers, small and large-scale suppliers, processors or canneries, as well as exporters (USAID, 2017; Firbiani, 2018). Sari (2015) explained that tuna supply chain in Indonesia were very complex, as illustrated that the Indonesian PL supply chain structure describes production inputs for bait and fuel, vertically integrated and fragmented fishers, types of fishers including household and industrial scales, type of fishing port; and distinction between domestic and export marketing distribution. Nevertheless, the results of research about 'Gender in tuna value chain: Case studies from Indonesia and Solomon Islands' (Barclay et al. 2020) noted that one notable difference between Indonesian and Solomon Islands tuna industries was the Indonesian value chain was much shorter because the fish product just passing through fewer businesses in the road from the ocean to the plates or dishes. By looking up Barclay et al. (2020) research results, the SKJ supply chain in Sikka-based PL fisheries (current research) also represented shorter than in Solomon Islands. It was realized that the results of current research were still lacking of quantification including the products, number of fishermen, and marketing performers and their business scales that was suggested for a supply chain study. On the other hand, a quantities approach can inform a better strategy of harvest strategy development because it is able to calculate a number of fishers affected and economic impacts. Therefore, quantitative research at the time of data collection is needed to complement the results of the current research.

\section{CONCLUSIONS}

The primary persons or performers and processes of skipjack supply chain on PL fishery based in Sikka consist of PL fishers (captain and crew), collectors and traders, processor companies and market. There were 67 active PL boats, which are supported by about 40 lift-nets (bagan) to provide 300-400 tonnes live bait, 11 small-medium scale and 5 large scale collectors and traders, 5 small scale and 4 large processors, and local, domestic, export market as well. From total 3556.9 tonnes SKJ caught by Sikka PL based in 2017, about $56 \%$ were processed as katsuobushi (smoke fish), which were mostly exported to Japan, $35 \%$ were processed as frozen SKJ, which were exported and marketed to Europe and USA, as well as domestic market, including Makassar, Bali and Surabaya, and the remain, about $9 \%$,were marketed to local consumers as cold-fresh SKJ.

\section{ACKNOWLEDGEMENTS}

Authors gratefully acknowledge the WPEA-SM project 2017 that funded this research and highly appreciate the observers and enumerators based in Sikka who have excellently carried out their duties.

\section{REFERENCES}

Athaillah, T., Hamid, A. H., \& Indra. (2018). Analisis efisiensi kinerja rantai pasok ikan tuna pada CV. Tuah Bahari dan PT Nagata Prima Tuna di Banda Aceh (Performance efficiency analysis of tuna fish supply chain at CV. Tuah Bahari and PT. Nagata Prima Tuna in Banda Aceh) (in Bahasa Indonesia). Marine Fisheries, 9(2), 169-181. DOI: https:// doi.org/10.29244/jmf.9.2.169-181

Baha, H. (2016). An Introduction of Descriptive Analysis, its advantages and disadvantages. Master of Public Policy and Good Governance. Leuphana University-Luneburg. 14pp. file:///C:/ Us e rs/user1/Down Io a d s/ Title_An_Introduction_on_Descriptive_Ana.pdf.

Bair, J. (2009). "Global commodity chain: genealogy and review" (p. 1-34), in Frontiers of Commodity Chain Research Ed. Bair, J (Stanford University Press, Palo Alto, CA).

Barclay, K. , McClean, N.D., Adhuri , S., Sulu, R., \& Fabinyi, M. (2020). Gender in tuna value chain: Case studies from Indonesia and Solomon Islands. SPC-The Pacific Community - Women in Fisheries. Information Bulletin \#31. 9 March 2020. Pp.1-11.

Beamon, B.M. (1998) Supply Chain Design and Analysis: Models and Methods. International Journal of Production Economics, 55(3), 281-294. Accessed 9.6.2020, http://citeseerx.ist.psu.edu/ v $\quad \mathrm{i} \quad \mathrm{e} \quad \mathrm{w} \quad \mathrm{d} \quad \mathrm{o}$ c l download?doi=10.1.1.129.9440\&rep=rep1\&type=pdf

Bjorndal, T., Child, A., \& Lem, A. (2014). Value chain dynamics and the small-scale sector: policy recommendations for small-scale fisheries and aquaculture trade. FAO Fisheries and Aquaculture Technical Paper No. 581. Rome, FAO. ISBN 97892-5-108178-5, E-ISBN 978-92-5-108179-2, 112 pp. 
Christopher, M. (2011). Supply Chain 2.0": managing supply chain in the era of turbulence. International Journal of Physical Distribution \& Logistics Management, 41(1), 63-82. DOI 10.1108/ 09600031111101439.

DKP Sikka, (2017). Laporan Tahunan Dinas Kelautan dan Perikanan Kabupa ten Sikka Tahun 2017 (Annual report of ma rine affairs and fisheries Sikka regency office 2017). Dinas Kelautan dan Perikanan, Jln. Litbang,, Kota Uneng, Alok, Kabupaten Sikka, Nusa Tenggara Tim. 50p.

Firbiani, M. (2018). Sustainable tuna supply chain to meet European market demand (A case study in Bitung). MSc Thesis Report (code: MST-80436), MSc Food Technology (Food Innovation and Management), Wageningen University and Research, 2018.57pp.

Gereffi, G., Humphrey, J., \& Sturgeon, T. (2005). The Governance of Global Value Chain. Review of International Political Economy, 12(1), 78-104.

Gibbon, P., Bair, J., \& Ponte, S. (2008). Governing global value chain: an introduction. Economy and Society, 37(3), 315-338. https://doi.org/10.1080/ 03085140802172656

Hosch, G. (2016). Design options for the development of tuna catch documentation schemes. FAO Fisheries and Aquaculture Technical Paper No. 596. Rome, FAO., ISSN-2070-7010, 262p. http:// www.fao.org/3/a-i5684e.pdf.

Inayati, A., 2019. Kerjasama Indonesia dan Interpol dalam penanggulangan Illegal, Unreported and Unregulated fishing (Collaboration between Indonesia and Interpol in overcoming Illegal, Unreported and Unregulated Journal of International Relations, 5(3), 467-473. or online in http://ejournal-s1.undip.ac.id/index.php/jihi.

Kaplinsky, R., \& Morris, M. (2001), A Handbook for Value Chain Research, prepared for the International Development Research Centre (IDRC), Book: 113pp (accessed 11.6.2020: http:// asiandrivers.open.ac.uk/documents/ Value_chain_Handbook_RKMM_Nov_2001.pdf.
Muhamad, S.V. (2012). Illegal fishing di perairan indonesia: permasalahan dan upaya penanganannya secara bilateral di kawasan (Illegal fishing in Indonesia waters: issue and efforts to deal with them bilaterally in the region). Jurnal Politica, Dinamika politik dalam negeri dan hubungan internasional, ISSN-2087-7900, 28p. http://jurnal.dpr.go.id/index.php/politica/article/ view/305.

Naziratil, H., Indra, \& Anwar, D. (2020). Performance analysis of skipjack tuna supply chain in Aceh Lampulo Jaya Bahari Ltd. RJOAS, 5(101), May 2020. DOI 10.18551/rjoas.2020-05.09. p. 84-93.

Petrere Jr., M., Giacomini, H.C., \& Jr. P. De Marco Jr. (2010). Catch-per-unit-effort: which estimator is best?, Braz. J. Biol, 70 (3), 483-491.

Sari, I. (2015. Understanding the capability of Indonesian shrimp producers to participate in lucrative export markets; using the integrated sustainable livelihoods approach (SLA) and global value chain (GVC) analyses, Ph.D thesis, University of Technology Sydney, Australia. 318pp.

Sutrisno, A., Kumar, V., Handayani, D., Arief, R.K., Virhian, S., \& Punuhsingon, C. (2019). Categorization of Supply Chain Sustainability Risks in SMEs: A Preliminary evidence from a Developing Country. Proceedings of the International Conference on Industrial Engineering and Operations Management Pilsen, Czech Republic, 23-26.

USAID. (2017). Value Chain Assessment Bitung, Indonesia. Jakarta: United States Agency for International Development/Regional Development Mission for Asia (USAID/RDMA).

Widodo, A.A., Wudianto., Sadiyah, L., Mahiswara., Proctor, C. \& Cooper, S. (2020). Investigation On Tuna Fisheries Associated With Fish Aggregating Devices (FADs) In Indonesia FMA 572 And 573. Ind. Fish. Res. J, 26(2), 97-105. DOI: http:// dx.doi.org/10.15578/ifrj.26.2.2020. p.97-105. 